\title{
Lowe-Kohn-Cohen syndrome
}

INSERM

\section{Source}

INSERM. (1999). Orphanet: an online rare disease and orphan drug data base. LoweKohn-Cohen syndrome. ORPHA:2408

Lowe-Kohn-Cohen syndrome is an extremely rare anorectal malformation syndrome characterized by imperforate anus, closed ano-perineal fistula, preauricular skin tag and absent renal abnormalities and pre-axial limb deformities. There have been no further descriptions in the literature since 1983. 